\title{
A facile synthesis of (tert-alkoxy)amines
}

\author{
Hasan Palandoken, Chris M. Bocian, Michelle R. McCombs and Michael H. Nantz
}

\begin{abstract}
Tertiary alcohols react with stoichiometric $\mathrm{BF}_{3} \cdot \mathrm{Et}_{2} \mathrm{O}$ and $N$-hydroxyphthalimide to yield $N$-alkoxyphthalimides. Subsequent hydrazinolyses afford the title compounds.
\end{abstract}

\section{Introduction}

The condensation of a ketone or aldehyde with an alkoxyamine (aka aminooxy) has emerged as a powerful means for labelling liposome, bacterial and mammalian cell surfaces as well as for chemoselectively ligating small molecule 'recognition elements' onto polyfunctional substrates. ${ }^{1}$ The robust oxime ether linkage formed in near quantitative yields in these reactions is ideal for applications in aqueous media; consequently, much effort has been devoted toward developing new, more efficient methods for the synthesis of alkoxyamines. $^{2-4}$ The existing methods for the preparation of alkoxyamines of the type $\mathrm{RONH}_{2}$ can be divided into two principal approaches: ${ }^{5}$ (i) hydroxyl group displacement and (ii) hydroxyl group amination. The former approach generally is performed using $N$-hydroxyphthalimide under Mitsunobu-like conditions ${ }^{2}$ or by using
$N$-protected hydroxylamine derivatives in nucleophilic substitution reactions. ${ }^{3}$ The amination approach, which has the advantage of retention of alcohol stereochemistry, requires an electrophilic reagent, such as an appropriately substituted oxaziridine (Eq. 1). ${ }^{4}$

As might be expected, both the displacement and amination strategies suffer when the starting hydroxyl substrate is a tertiary alcohol. Indeed, most of the few reported syntheses of (tert-alkoxy)amines are characterized by modest to low yields. ${ }^{4,6-8} \mathrm{We}$ recently required access to sterically hindered alkoxyamines and, as a consequence, we developed an alternative method for their preparation. Herein, we describe the straightforward conversion of tertiary alcohols $\mathbf{1}$ (Table 1) to the corresponding (tert-alkoxy)amines $\mathbf{3}$ as well as conditions for isolation of low-molecular weight, water soluble members of this class of compounds.
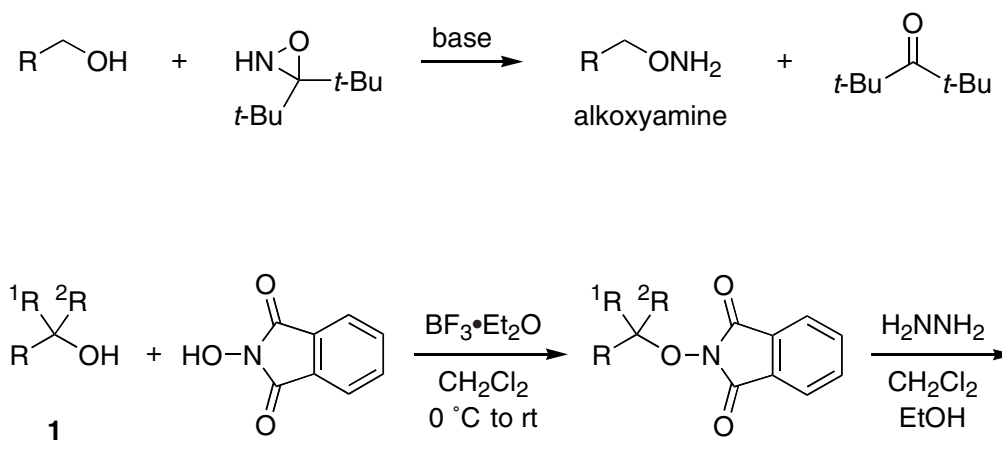<smiles>[R]C([R])([3H])ON1C(=O)c2ccccc2C1=O</smiles>

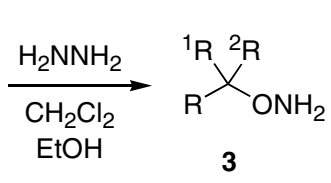

3 
Table 1. Synthesis of (tert-alkoxy)amines ${ }^{\mathrm{a}}$

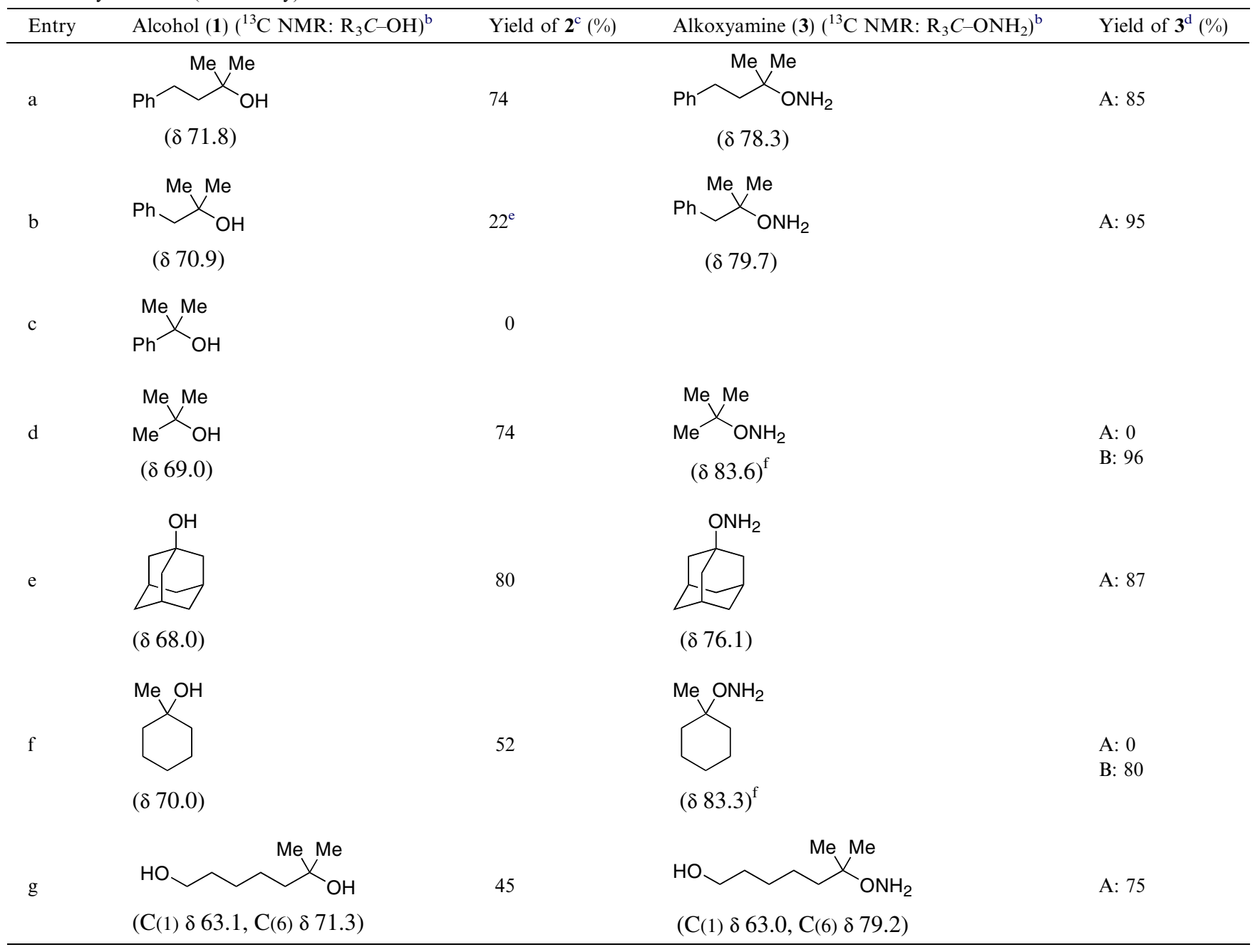

${ }^{a}$ All reactions were performed on $\geqslant 1 \mathrm{mmol}$ scale.

${ }^{\mathrm{b}}$ Taken in $\mathrm{CDCl}_{3}$.

${ }^{\mathrm{c}}$ Isolated yield from $\mathbf{1}$.

${ }^{\mathrm{d}}$ Isolated yield from 2 using either Method A (aqueous work-up) or Method B (anhydrous conditions).

${ }^{\mathrm{e}}$ Major product is $\beta, \beta$-dimethylstyrene (69\%).

${ }^{\mathrm{f}} \mathrm{HCl}$ salt.

\section{Results}

The simple treatment of tertiary alcohols with stoichiometric $\mathrm{BF}_{3} \cdot \mathrm{Et}_{2} \mathrm{O}$ and $N$-hydroxy-phthalimide in $\mathrm{CH}_{2} \mathrm{Cl}_{2}$ proceeds to give the corresponding $O$-alkyl phthalimides 2 in fair to good yields (Table 1, entries a, d-f). The use of TMSOTf or other Lewis acids to facilitate this transformation was less effective. In cases where alcohol elimination would provide a conjugated alkene (e.g., entries $\mathrm{b}$ and $\mathrm{c}$ ), formation of the desired substitution product was minimal to nonexistent. We reasoned that $N$ hydroxyphthalimide did not competitively intercept the putative carbenium ion formed on alcohol reaction with $\mathrm{BF}_{3}$ due, in part, to its poor solubility in $\mathrm{CH}_{2} \mathrm{Cl}_{2}$. However, our attempts at solubilizing $N$-hydroxyphthalimide using several polar and mixed solvent systems did not improve product yields in these facile elimination cases. We also noted that secondary alcohols do not afford $N$ hydroxyphthalimide substitution products under the $\mathrm{BF}_{3}$ conditions. The reactions of cyclohexanol and 2- dodecanol resulted only in recovered starting alcohol. These results suggested the possibility for a chemoselective alcohol to alkoxyamine transformation. We examined this event using 6-methylheptane-1,6-diol (entry g) and found that only its tertiary alcohol reacted to give alkoxyamine $\mathbf{3 g}$.

Cleavage of the phthalimide groups of $\mathbf{2 a}-\mathbf{b}, \mathbf{e}, \mathbf{g}$ using standard hydrazinolysis conditions (Method A: excess hydrazine hydrate, $\left.1: 5 \mathrm{CH}_{2} \mathrm{Cl}_{2}-\mathrm{EtOH}, \mathrm{rt}, 12 \mathrm{~h}\right)^{9}$ gave the (tert-alkoxy)amine products in good yields. ${ }^{10}$ The consistent, slight ${ }^{13} \mathrm{C}$ NMR downfield shift of the alkoxyamine $\mathrm{ONH}_{2}$-bearing carbon relative to starting alcohol is a convenient means for analyzing the transformation (see Table 1). The cleavage products of phthalimides $2 \mathbf{d}$ and $2 \mathbf{f}$ had appreciable solubility in water and this precluded their straightforward isolation. However, by adopting a non-aqueous method for phthalimide cleavage (Method B: methylhydrazine, $\mathrm{CH}_{2} \mathrm{Cl}_{2}$; $\mathrm{HCl}),{ }^{11}$ we were gratified to isolate alkoxyamines $\mathbf{3 d}$ 
and $3 \mathbf{f}$ as their hydrochloride salts in good yields. ${ }^{10}$ In our experience, application of this method to other low-molecular weight phthalimides also dramatically improved product isolation (e.g., Eq. 2; Method A: $7 \%$, Method B: $98 \%$ ).

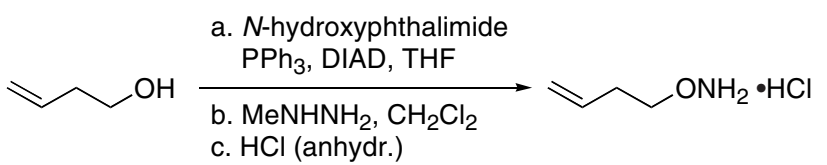

\section{Representative anhydrous hydrazinolysis (Method B)}

To a solution of $N$-(tert-butoxy)phthalimide $2 \mathbf{d}(1.0 \mathrm{~g}$, $4.6 \mathrm{mmol})$ in $\mathrm{CH}_{2} \mathrm{Cl}_{2}(15 \mathrm{~mL})$ at $0{ }^{\circ} \mathrm{C}$ was added methylhydrazine $(0.32 \mathrm{~mL}, 6.0 \mathrm{mmol})$ dropwise. The reaction was gradually warmed to room temperature and stirred for $12 \mathrm{~h}$. After re-cooling to $0^{\circ} \mathrm{C}$, the reaction mixture was filtered to remove precipitated solids. $\mathrm{HCl}(\mathrm{g})$ then was bubbled through the filtrate at $0{ }^{\circ} \mathrm{C}$ for $15 \mathrm{~min}$. The resulting slurry was stirred at $0{ }^{\circ} \mathrm{C}$ for an additional $30 \mathrm{~min}$ and subsequently filtered. Concentration of the filtrate in vacuo afforded $\mathbf{3 d}$ as an off-white solid $(0.55 \mathrm{~g}, 96 \%)$. Mp $154.0-155.4{ }^{\circ} \mathrm{C} ;{ }^{1} \mathrm{H}$ NMR $\left(\mathrm{CDCl}_{3}\right)$ : $\delta 1.43(\mathrm{~s}, 9 \mathrm{H}), 10.57$ (br s, 3H); ${ }^{13} \mathrm{C}$ NMR $\left(\mathrm{CDCl}_{3}\right)$ : $\delta$ 26.6, 83.6.

In conclusion, we have presented a straightforward twostep method for the transformation of tertiary alcohols to (tert-alkoxy)amines. The method uses inexpensive reagents and is amenable to large scale synthesis.

\section{Acknowledgements}

This work was supported by the National Institutes of Health (NS-046591).

\section{References and notes}

1. For recent examples, see: (a) Lemieux, G. A.; Yarema, K. J.; Jacobs, C. L.; Bertozzi, C. R. J. Am. Chem. Soc. 1999, 121, 4278-4279; (b) Perouzel, E.; Jorgensen, M. R.; Keller, M.; Miller, A. D. Bioconjug. Chem. 2003, 14, 884-898; (c) Sadamoto, R.; Niikura, K.; Ueda, T.; Monde, K.; Fukuhara, N.; Nishimura, S.-I. J. Am. Chem. Soc. 2004, 126, 3755-3761.
2. (a) Grochowski, E.; Jurczak, J. Synthesis 1976, 682-684; (b) Nicolaou, K. C.; Groneberg, R. D. J. Am. Chem. Soc. 1990, 112, 4085-4086; (c) Su, S.; Giguere, J. R.; Schaus, S. E., Jr.; Porco, J. A., Jr. Tetrahedron 2004, 60, 8645-8657.

3. (a) Kim, J. N.; Kim, K. M.; Ryu, E. K. Synth. Commun. 1992, 22, 1427-1432; (b) Jones, D. S.; Hammaker, J. R.; Tedder, M. E. Tetrahedron Lett. 2000, 41, 1531-1533; (b) Marcaurelle, L. A.; Shin, Y.; Goon, S.; Bertozzi, C. R. Org. Lett. 2001, 3, 3691-3694; (c) Carrasco, M. R.; Brown, R. T.; Serafimova, I. M.; Silva, O. J. Org. Chem. 2003, 68, 195-197.

4. (a) Choong, I. C.; Ellman, J. C. J. Org. Chem. 1999, 64, 6528-6529; (b) Foot, O. F.; Knight, D. W. Chem. Commun. 2000, 11, 975-976.

5. For recent syntheses of $N$-substituted alkoxylamines, see: (a) Braslau, R.; Tsimelzon, A.; Gewandter, J. Org. Lett. 2004, 6, 2233-2235; (b) Grubbs, R. B.; Wegrzyn, J. K.; Xia, Q. Chem. Commun. 2005, 80-82, and references cited therein.

6. Mavunkel, B. J.; Rzeszotarski, W. J.; Kaplita, P. V.; DeHaven-Hudkins, D. L. Eur. J. Med. Chem. 1994, 29, 659-666.

7. Bicknell, A. J.; Gasson, B. C.; Hardy, K. D. EP-386940, 1990.

8. (a) Chimiak, A.; Kolasa, T. Bull. Acad. Pol. Sci. 1974, 12, 195-198; (b) Labeeuw, O.; Phansavath, P.; Genêt, J.-P. Tetrahedron Lett. 2004, 45, 7107-7110.

9. Sasaki, T.; Minamoto, K.; Itoh, H. J. Org. Chem. 1978, 43, 2320-2325.

10. Alkoxyamines $\mathbf{3 b}, \mathbf{d}-\mathbf{f}$ have been previously described. Characterization data for the new compounds is as follows: Compound 2a: $\mathrm{mp}$ 78.6-80.1 ${ }^{\circ} \mathrm{C}$; ${ }^{1} \mathrm{H}$ NMR $\left(\mathrm{CDCl}_{3}\right): \delta 1.42(\mathrm{~s}, 6 \mathrm{H}), 1.98(\mathrm{~m}, 2 \mathrm{H}), 2.86(\mathrm{~m}, 2 \mathrm{H}), 7.15$ $(\mathrm{m}, 1 \mathrm{H}), 7.27(\mathrm{~m}, 4 \mathrm{H}), 7.63(\mathrm{~m}, 2 \mathrm{H}), 7.74(\mathrm{~m}, 2 \mathrm{H}) ;{ }^{13} \mathrm{C}$ NMR $\left(\mathrm{CDCl}_{3}\right): \delta 25.2,30.5,42.3,88.0,123.1,123.2,125.7$, 128.3, 129.1, 134.3, 142.2, 165.5; HRMS $\left[\mathrm{M}+\mathrm{Na}^{+}\right]$Calcd for $\mathrm{C}_{19} \mathrm{H}_{19} \mathrm{NO}_{3}$ : 332.1257 , found: 332.1262. Compound 3a: ${ }^{1} \mathrm{H}$ NMR $\left(\mathrm{CDCl}_{3}\right): \delta 1.36(\mathrm{~s}, 6 \mathrm{H}), 1.99(\mathrm{~m}, 2 \mathrm{H}), 2.76$ $(\mathrm{m}, 2 \mathrm{H}), 4.93$ (br s, $2 \mathrm{H}), 7.35(\mathrm{~m}, 5 \mathrm{H}) ;{ }^{13} \mathrm{C} \mathrm{NMR}\left(\mathrm{CDCl}_{3}\right)$ : $\delta$ 24.4, 30.5, 40.8, 78.3, 125.6, 128.3, 142.9; HRMS $\left[\mathrm{M}+\mathrm{Na}^{+}\right]$Calcd for $\mathrm{C}_{11} \mathrm{H}_{17} \mathrm{NO}$ : 202.1202, found: 202.1206. Compound $2 \mathrm{~g}$ : $\mathrm{mp} 55.5-56.6{ }^{\circ} \mathrm{C}$; ${ }^{1} \mathrm{H}$ NMR $\left(\mathrm{CDCl}_{3}\right): \delta 1.36(\mathrm{~s}, 6 \mathrm{H}), 1.59(\mathrm{~m}, 8 \mathrm{H}), 3.68(\mathrm{t}, J=6.6 \mathrm{~Hz}$, $2 \mathrm{H}), 7.76(\mathrm{~m}, 2 \mathrm{H}), 7.84(\mathrm{~m}, 2 \mathrm{H}) ;{ }^{13} \mathrm{C} \mathrm{NMR}\left(\mathrm{CDCl}_{3}\right): \delta$ 24.3, 25.4, 26.4, 32.9, 40.6, 63.0, 89.1, 123.7, 129.5, 134.7, 166.1; HRMS [M+Na ${ }^{+}$Calcd for $\mathrm{C}_{16} \mathrm{H}_{21} \mathrm{NO}_{4}$ : 314.1363, found: 314.1362. Compound 3g: ${ }^{1} \mathrm{H}$ NMR $\left(\mathrm{CDCl}_{3}\right): \delta 1.09$ $(\mathrm{s}, 6 \mathrm{H}), 1.29(\mathrm{~m}, 4 \mathrm{H}), 1.50(\mathrm{~m}, 4 \mathrm{H}), 3.58(\mathrm{t}, J=6.6 \mathrm{~Hz}$, 2H), 3.81 (br s, $2 \mathrm{H}) ;{ }^{13} \mathrm{C} \mathrm{NMR}\left(\mathrm{CDCl}_{3}\right): \delta 24.1,24.6,26.6$, 33.0, 39.1, 63.0, 79.2; HRMS $\left[\mathrm{M}+\mathrm{Na}^{+}\right]$Calcd for $\mathrm{C}_{8} \mathrm{H}_{19} \mathrm{NO}_{2}$ : 184.1308, found: 184.1306 .

11. We modified the procedure described in the following reference to obviate column chromatography: Bailey, S.; Harnden, M. R.; Jarvest, R. L.; Parkin, A.; Boyd, M. R. J. Med. Chem. 1991, 34, 57-65. 